\title{
QUANTIFYING THE ORDER OF PRIORITIES IN STUDENT CHOICE OF GRADUATE BUSINESS SCHOOLS Does Sustainability Matter?
}

\author{
ROBERT SROUFE (corresponding author) \\ John F. Donahue Graduate School of Business \\ Duquesne University, Pennsylvania, U.S.A. \\ sroufer@duq.edu \\ DAVID B. BRAUER \\ John Chambers School of Business \& Economics \\ West Virginia University, West Virginia, U.S.A. \\ dave@prioritybridge.com
}

\begin{abstract}
Business schools expend resources to attract more and higher-quality applicants to their institutions, yet our understanding of what criteria resonate with those who want to find the right fit with a business school and its programs is, paradoxically enough, either not clear or dated. There is a dearth of research on what business students value, resulting in missed opportunities to engage existing students so as to translate their interests and aspirations into prospects for program design, delivery, and enrollment. One important and often overlooked criterion, for example, is the desire of business students to learn about sustainability. Thus, while most studies aim to discover and quantify the selection criteria in students' choice of business schools, this paper builds on the aspect of sustainability. We propose a multi-criteria decision analysis (MCDA) methodology that uncovers an array of essential criteria, including sustainability, for schools to consider in future program revision and development efforts. The proposed approach allows schools to be exact with their resource expenditures in areas that are critical to applicants, including those aligned with sustainability, as well as attract larger numbers of more qualified students. Insights from this study show that with the proper approach to understanding business school candidates, it is possible to quantify the order of priorities that students consider when choosing a business school.
\end{abstract}

\section{KEYWORDS}

applicant criteria; business schools; global sustainability;

higher education institution; mixed methods; multi-criteria decision-making 


\section{INTRODUCTION}

Business schools are at a crossroads. With various parts of the world experiencing the effects of climate change, volatility in global economic markets, social unrest, and a pandemic, applicants are left with questions about their future. The dynamics of business school programs are changing, enrollments have decreased in recent years, the pandemic has forced many into online-only teaching and learning, and there are predictions that some business school programs and even entire colleges are closing for good. Given such complex times, does sustainability even matter for those applying to business schools? Sustainability, for the purposes of this study, is operationalized based on the Brundtland Commission's definition of sustainable development, i.e., using environmental, social, and economic practices to meet the needs of a current generation without compromising the ability of future generations to meet theirs (WCED, 1987).

It has been understood for over a half-century that a good education increases the earning ability, economic value, and human capital of individuals (Zhang, 2005; English, 2012). Is there more that we can do, then, to understand what applicants want from business school programs? Are there other considerations for incoming students, such as learning skills for catalyzing change? Bower and Paine (2017) have shed new light on the persistent error at the heart of corporate leadership and its perpetuation in business schools. Not only have they found flaws in the agencybased model that is at the foundation of most of today's business school teaching, but they may have also foreshadowed the kind of change that applicants to business school programs want. Instead of a myopic view of the fiduciary responsibility of a firm, which is to create value only for shareholders, what if business students want programs and degrees that deliver skillsets and insights that allow them to align future business practices with a diverse economic value proposition and elements of the United Nations' 17 Sustainable Development Goals (SDGs)? Waddock (2020) gets at this by asking if "business schools are able to meet the grand challenges of the era" with calls for collaboration, stewardship, and connection to others. 


\section{SUSTAINABLE GELPI:A
DEVELOPMENT}
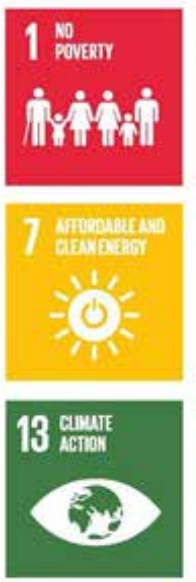
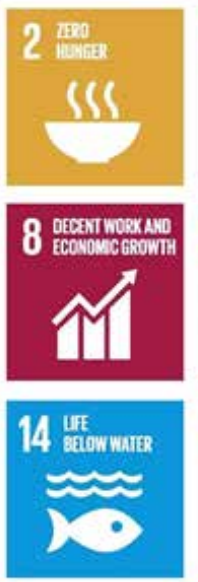
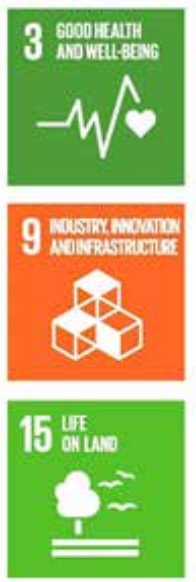
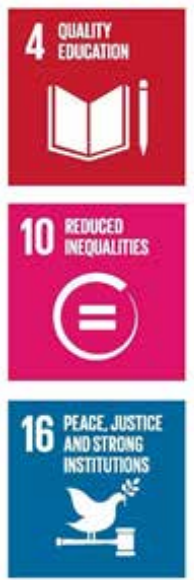
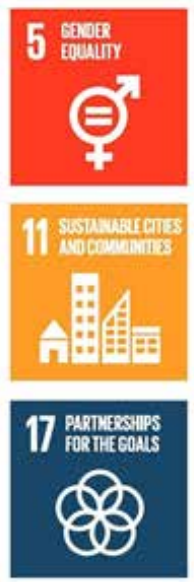
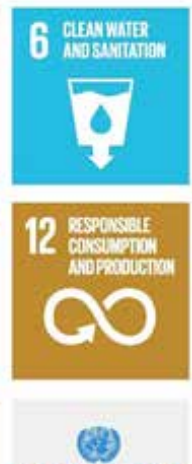

SUSTAINABLE DEVELOPMENT GOALS

Figure 1: The United Nations' Sustainable Development Goals

In this study, we propose that applicants to business schools want more than just "business as usual." As we explore the changing business school landscape, we also propose a method for gathering and interpreting the data necessary for grasping the type of changes desired by incoming students and other stakeholders. This will hopefully provide opportunities for resilient business schools to meet the challenges of this new era in global management education as well as new insights and an opportunity to be out in front of emerging trends. We define resilient schools the same way we would resilient businesses-as "having the capacity to absorb stress, recover critical functionality, and thrive in altered circumstances" (Reeves \& Whitaker, 2020). Indeed, higher education institutions (HEIs) have recognized several issues threatening their survival.

HEIs, not unlike other businesses, are subject to fulfilling their customers' (i.e., students') needs. Yet most schools lack experience operating in an aggressive environment (Card \& Card, 2007), and the economic crisis has had a negative impact on endowments and the ability of students to pay for the increasing costs of education (Carter \& Yeo, 2009). Add to this the current pandemic, moreover, and one will find that decreased incomes have not been offset by decreased expenses in many cases. Ballooning fiscal pressures, reduced applications, emerging global markets, and cyber competition are all challenges facing the schools of business today. 
A market-oriented organization understands its customers, adjusts constantly to changing factors, and communicates robustly with both its internal and external stakeholders (Parvu \& Ipate, 2012). However, have schools and their administrators asked what happens if a continued focus on the neoliberal paradigm of economics is no longer aligned with applicants' changing wants and employers' needs in a global business management landscape? Business school programs depend heavily on quantitative analysis in their curricula and tend to leave unfulfilled the teaching of necessary soft skills such as communication, which are critical to becoming effective managers (Simpson, 2006; Slater \& Dixon-Fowler, 2010).

Virtually every company in the Standard \& Poor's (S\&P) 500 develops annual sustainability reports, follows Global Reporting Initiative (GRI) guidelines, and links performance to the U.N. SDGs (3BL Media, 2020; Brown, 2013). Yet studies by Navarro (2008) and Rubin and Dierdorff (2009) found supporting evidence for the lack of curricula in such areas as required by present-day managers (Slater \& Dixon-Fowler, 2010). Are HEIs keeping up with these global efforts to measure, manage, and report sustainability initiatives? Improved stakeholder understanding and satisfaction have a positive impact on HEIs' finances; indeed, the link connecting stakeholder satisfaction with improved finances is asymmetrical (Gupta \& Zeithaml, 2006). Paraschivescu and Radu (2011) wrote that "the most important challenge for universities is to adjust their structure for new expectations in the $21^{\text {st }}$ century" (p. 119). There thus appears to be an increased awareness surrounding the benefits of co-curricular activities when it comes to assisting students attain necessary skills. These types of engagements "help students develop self-awareness, autonomy, self-worth, altruism, reflective thought, interpersonal skills, and decision-making skills" (Rusinko, 2010: 509).

Yet while research in this area will help institutions design new programs and rethink existing ones, we could not find any to date that has quantified business students' selection criteria for which school best fits them. The review of business school critiques is deficient in empirical studies (Pfeffer \& Fong, 2002; Slater \& Dixon-Fowler, 2010) which are essential as a business school's ability to differentiate itself from others is critical for supporting marketing, program development, and recruitment efforts. It will enhance an institution's ability to attract prospective students and recruiters (Hammond \& Webster, 2011). This present study, therefore, has significant relevance for business schools concerning their resource allocation 
and long-term strategic planning. When it is possible to quantify the criteria students prioritize and use in choosing a school, administrators and decision-makers can devise and map out a path toward essential selection criteria that include sustainability and the U.N. SDGs.

This study's primary research questions are as follows: What are the criteria prospective students use to choose business schools? What is the relative importance of various criteria? What is the order of the difference between these relationships? Does sustainability matter, moreover, when studying these questions? Given that organizations with a market focus continually review their goals and established support systems, the viability of HEIs can be determined based on their understanding of the "needs of potential customers and [on] being prepared to adapt technology to suit them" (Bailey, 1991: 448; Brauer, 2012). An understanding of the criteria students use when deciding to attend a particular institution is essential, therefore, to align the objectives of HEIs.

\section{ISSUES FACING GRADUATE BUSINESS SCHOOLS}

As the challenges schools are now facing are too many to dive into in the space of this study, we focus our attention on declining enrollments, retention, changing competencies needed in the workplace, the integration of global sustainability, and relevance. We then look at the issues of differentiation and resistance to change before transitioning to the need for understanding what students want.

\section{Declining Enrollment}

Declining student enrollment places many middle-ranking HEIs in the position of having to make some tough program decisions in the immediate future. One study in the United Kingdom accurately forecasted a 6\% decline in students by 2019 (Dobson, Quilley, \& Young, 2010). This is a result of the declining birthrate in many developed countries, including the U.S. (Tavares \& Cardoso, 2013; see also the Chronicle of Higher Education report on the looming enrollment crisis [Kelderman \& Gardner, 2019]). Those seeking an education are also no longer restricted to a local choice; instead, there is a global market for education at colleges and universities that have become "hypercompetitive" (Carter \& Yeo, 2009: 167; Tavares \& Cardoso, 2013). Many countries are now imposing stricter guidelines for visas as well, resulting 
in greater competition among those students able to obtain the necessary documents but which in turn leads to reduced demand (Carter \& Yeo, 2009).

\section{Retention}

Business schools are challenged to obtain new students and retain them until graduation, a fact exacerbated by the declining birth rate in developing countries and the economic pressures felt by prospective students and their families (Punj \& Staelin, 1978). For many institutions, maintaining the student population at the very least is critical to prevent having to discontinue some of their class offerings and reduce their hazard of mortality (Vander Schee, 2009). The fact that student retention has a linear relationship with financial results (Gupta \& Zeithaml, 2006), however, can price the HEI out of the market range for many prospective enrollees in situations where the education is cost-sensitive.

\section{Changing Competencies}

Business schools need to produce graduates with competencies that meet the requirements of international business. Multiple academic papers have cited business school programs as being out of touch with such needs (Pfeffer \& Fong, 2002; Slater \& Dixon-Fowler, 2010). Global organizations are hiring individuals capable of working in a global environment while meeting global goals, making a greater emphasis on interdisciplinarity and international business acumen a differentiator in the education industry (Datar, Garvin, \& Cullen, 2010). A positive differentiation from other business schools can help a HEI attract quality students and recruiters, nurture employee loyalty, and create a proper market focus for the institution (Hammond \& Webster, 2011). Early adopters of sustainability, for example, can be found among the signatories of the U.N. Principles for Responsible Management Education (PRME). The competitiveness of the institution's offerings is also a critical focus area for business schools when attracting future applicants. Such offerings can include courses and entire programs that integrate management and sustainability within the curriculum (Sroufe, 2018).

Integration of Global Sustainability

In 2009, Rubin and Dierdorff analyzed the management coursework of 373 universities accredited by the Association to Advance Collegiate Schools of Business (AACSB) and discovered failures to incorporate relevant course content that included 
essential corporate management aspects. Competencies related to human capital management and managing a decision-making process were found deficient in the curricula, leading them to conclude that business school programs "have adopted a form of pluralistic ignorance in which stakeholders seem to agree on what competencies ought to be emphasized privately, but fail to manage such agreement in practice, inevitably maintaining the curricular misalignment that remains so persistent" (Rubin \& Dierdorff, 2011: 154).

To remedy this situation, the AACSB now includes "engagement and societal impact" as a focal accreditation area where they see business schools and businesses as forces for good in society, able to address significant issues on a local, national, and international scale. Indeed, we also see organizations such as the Aspen Institute as well as the Corporate Knights ranking of sustainability integration in MBA programs as realigning competencies needed in the workplace. These corporate management competencies include measuring and managing environmental, social, and governance (ESG) performance.

Too many business school programs are focused on a "profits-first" mentality in their curricula (Ghoshal, 2005; Giacalone \& Thompson, 2006; Slater \& DixonFowler, 2010). This opportunistic-oriented educational format and emphasis on the bottom line can be responsible in part for the unethical behavior of businesses and their executives (Henle, 2006). We thus highlight three key findings of the $2014 \mathrm{Net}$ Impact Business as Unusual guide (Net Impact, 2014). First, future leaders forecast a significant increase in the social and environmental concerns of how businesses operate. As a consequence, students expect a greater emphasis on discussing sustainability integration in their curricula. Lastly, business school programs will be required to focus on curricula that create increased employment opportunities (Hoffman, 2018).

\section{Relevance and Differentiation}

Many institutions have remained unchanged and have not kept up their relevance in society. Indeed, some of these schools may even be forced to close their doors-according to the Business of Branding Report published by the European Foundation for Management Development and CarringtonCrisp, most business schools' products are similar and prospective students see little differentiation from one institution to another (CarringtonCrisp, EFMD, \& ABS, 2013). Schools 
of business must differentiate themselves to maintain a competitive advantage (Montgomery \& Ramus, 2011; Gopalan, Pagiavlas, \& Jones, 2008). To be viable at all, moreover, a segment of differentiation must be identifiable, have a large enough mass to be considered, and possess unique needs. The demographics and segmentation of the population attracted to the segment also need to be identified and analyzed (Parvu \& Ipate, 2012).

Various rankings of HEIs also end up fragmenting their offerings in the eyes of prospective applicants, who then have an independent reading of the institutions for their disciplines of interest. These institutions, which constantly provide a mix of disparate offerings in their attempts to meet the needs of a multiplicity of stakeholders, need to choose their niches so they can allocate their resources optimally toward the best desired outcome. The product offerings of HEIs, in particular, need to reflect the current needs of organizations that are hiring their graduates. The more competitive these offerings are, the more applicants will be attracted to the institutions that provide them.

\section{Resistance to Change}

HEIs have historically been adverse to change (Barnett \& Shore, 2009; Blass \& Hayward, 2014). This is not unique to the educational field-many organizations in established industries and that have complex established structures suffer from deliberate resistance to change, which is often referred to as inertia. Since consumers demand consistency, organizations will resist change to satisfy them (Negro, Hannan, Rao, \& Leung, 2007).

When approaching change, some first movers seek out state-of-the-art approaches and invent new technologies to implement such. This is strategic flexibility, i.e., when an organization can "identify major changes in the environment and quickly commit resources to a new course of action in response to those changes" (Shimizu $\&$ Tamura, 2012). Examples of this flexibility can be seen in the early years of MBA program rankings that integrate sustainability, such as in the Aspen Institute's

"green" MBA guide which was meant to help prospective students find socially responsible MBA programs (Aspen Institute, 2008). Indeed, while innovation is risky, "failure to adapt and adopt will see institutions losing their future students" (Barth, 2013: 1). 
Changing a HEI's core features, however, is "especially destabilizing" (Hannan, Baron, Hsu, \& Koçak, 2006: 755). One such core feature of a university is its curriculum, which provides the HEI with an identity and dictates resource distribution. Changes such as making room for sustainability as part of the curriculum threaten established identities, yet institutional change is what moves an organization from where it is now to a more desirable alternative (Lozano, Ceulemans, \& Seatter, 2015). Business schools are under enormous pressure from accreditations and rankings that create standardization but which now consider ESG performance as an essential element of the curriculum.

Impediments to change include a lack of data in support of the opportunity, faculty resistance, a lack of faculty to teach new subject matter, a lack of interest and understanding among faculty, staff, and other stakeholders, and many disciplines competing for restricted space in the curriculum (Rasche, Gilbert, \& Schedel, 2013). Change does not come easy to organizations that have been teaching the same curriculum for half a century without regard for the environment and social impact. "Organizational changes that threaten the status quo, such as moving away from unsustainable practices towards more sustainable ones, are bound to face resistance at different organizational levels" (Lozano et al., 2015: 207). Such changes can often "confuse and anger" stakeholders (Hannan et al., 2006: 756).

The core features most challenging to alter are "mission, form of authority, [and] core technology, i.e., employees' skills and marketing strategies" (Hannan et al., 2006: 756). Changing these creates questions coming from all stakeholders about the organization's crux as "opportunities" for change can encounter more resistance than acceptance. Survival is thus enhanced by effectively communicating well thought-out plans that embrace new data, reliability, and accountability (Hannan et al., 2006). Change is perilous indeed, though a lack of it can sometimes be fatal.

Figure 2 depicts a conceptual model of the issues, obstacles, and opportunities that business schools are facing today. Administrators can thus view the marketing of their programs "as both a viable philosophy, and a strategy for developing [a higher education] sector" (Hemsley-Brown \& Oplatka, 2006), a sector that will be producing graduates who need to tackle real-world problems while meeting the expectations and needs of its incoming members at the same time. 


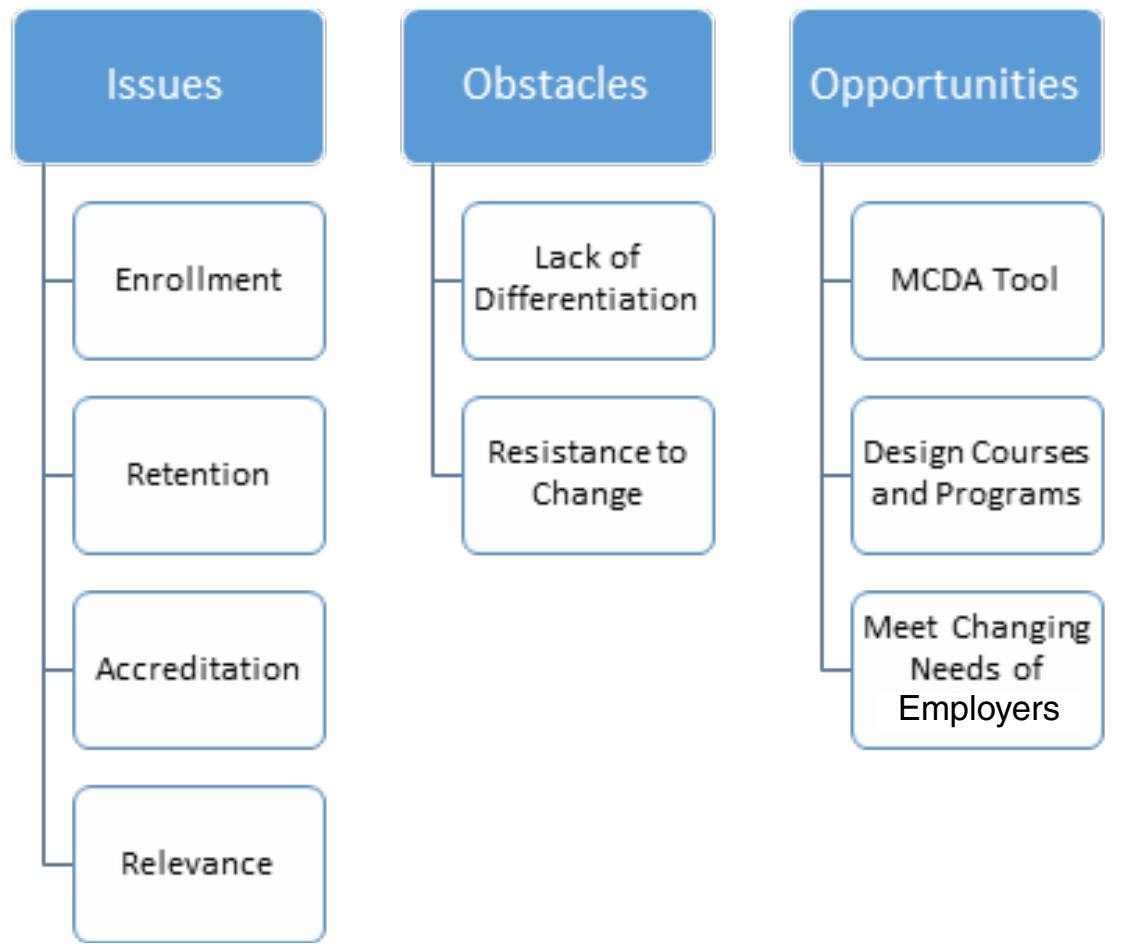

Leverage Changing Needs of Potential Students

Figure 2: Issues, Obstacles, and Opportunities Faced by Business Schools

\section{UNDERSTANDING WHAT STUDENTS WANT (CRITERIA)}

We now review the research as to why a prospective graduate student chooses one HEI over another. Indeed, even with the limited claims of studies in this area (Chapman, 1986; Kallio, 1995; Montgomery, 2002; Blackburn, 2011; English, 2012), we have identified several essential criteria and methods used to identify such. A 2008 analysis of over 500 business school students in particular considered the following student selection criteria: availability of on-campus housing, availability of international studies, racial diversity of students, residential requirements of programs, class sizes, reputation of the staff, availability of financial aid, tuition, length of programs, and reviews and reputation of the institution (Ivy, 2008). We 
used these same criteria as a foundation for this present study, drew from others in the literature, and conducted a qualitative interview.

We found a study on student selection by Webster, Hammond, and Rothwell (2010) along with another by Hammond and Webster (2011) that looked at the criteria students used in choosing an educational institution. Important insights from these studies include findings that marketing efforts focused on the students have the quickest and best payback for institutions of higher education and that institutions with a greater degree of marketing orientation perform at a higher level (Webster, Hammond, \& Rothwell, 2010; Hammond \& Webster, 2011).

In 2011, a study of 76 business students at the University of Queensland identified five key criteria: reputation of the university, quality of the facilities and academic standing of the institution, perception of students regarding available curricula and time required to complete the studies, perceptions of the campus and department, and students' perceptions of return on investment (Blackburn, 2011). Other similar studies have been conducted, the majority of which were quantitative using Likert scales. Researchers in a 2007 study, for instance, conducted telephone interviews with deans at 50 of the top graduate business schools in the United States (Christensen, Peirce, Hartman, Hoffman, \& Carrier, 2007; Franceschini, Wang, \& Cort, 2015; Hammond, Harmon, \& Webster, 2007; Essary, 2011).

Traveling abroad for education is also not a new concept in a global economy. "Students have been traveling internationally to study in countries not their own [since] 600BC" (Gatfield \& Chen, 2006: 78). The United States has been the leader in providing studies globally since the mid-1940s, with its education system being the country's second-largest export market. Increased competition for recruiting and retaining the best students is especially true, therefore, among HEIs in the United States (Chapman, 1981; Kallio, 1995; Padlee, Kamaruddin, \& Baharun, 2010). Indeed, "as countries seek to gain [an] advantage of global optimisation of their share of international students, it will become increasingly important to engage in extensive consumer behaviour research" (Gatfield \& Chen, 2006: 93).

One study in 1995 concluded that an institution's reputation and ranking make up the most critical criteria for students (Kallio, 1995). Any institution or organization is compared to its peers based on its performance and ability to provide value to 
its consumers. Institutions of higher education need to provide their students with superior performance, which in turn encompasses the audience's perception of the institution as well as of the offerings they make. There is a strong correlation indeed between student satisfaction, reputation, and loyalty (Thomas, 2011).

We do not see any mention of sustainability, however, in these earlier studies. The emergence of sustainability and the growing importance of environmental management are more recent phenomena as reflected by what workers want to study (Net Impact, 2012; Gerard, 2014). Respondents in a global survey of students from top-ranked business schools said that they do not want to work for companies with bad environmental practices, that they consider environmental actions to be profitable and even note that environmental protection will improve economic growth and provide new jobs (Net Impact, 2012; Franceschini et al., 2015).

The choice of prospective students is influenced at first by factors that include their religious affiliations, gender, and parents' level of education (Chapman, 1986; Mullen, Goyette, \& Soares, 2003). With a limited number of top-ranked schools, however, the focus eventually turns to differentiation. This is where we can see the creation of a list of search criteria for the multiple-criteria complex-decision making of students as well as the opportunity for coming up with decision analysis tools that enable business schools to understand the needs of their applicants better. Students typically want to be with others whose aptitude is similar to their own. Other criteria they consider are the distance from home, location of the HEI, facilities available on campus, tuition cost, average starting salary of graduates, and programs offered along with their availability (Chapman, 1981; Padlee et al., 2010; English, 2012). To attract prospective students, institutions must provide offerings that are competitive and meaningful for future employers especially given that students look for a HEI where their probabilities of success will be the greatest (Arnold, Chakravarty, \& Balakrishnan, 1996; Montgomery \& Ramus, 2011). Table 1 summarizes these critical factors along with those from other studies. 


\begin{tabular}{|c|c|c|c|c|c|c|c|}
\hline Criteria & $\begin{array}{c}\text { Punj \& } \\
\text { Staelin, } \\
1978\end{array}$ & $\begin{array}{c}\text { Chapman, } \\
1981\end{array}$ & $\begin{array}{c}\text { Kallio, } \\
1995\end{array}$ & $\begin{array}{l}\text { Christensen } \\
\text { et al., } 2007\end{array}$ & $\begin{array}{l}\text { Ivy, } \\
2008\end{array}$ & $\begin{array}{l}\text { Padlee } \\
\text { et al., } \\
2010\end{array}$ & $\begin{array}{c}\text { Blackburn, } \\
2011\end{array}$ \\
\hline $\begin{array}{l}\text { On-Campus } \\
\text { Housing }\end{array}$ & & & & & $\mathrm{X}$ & $\mathrm{X}$ & \\
\hline $\begin{array}{c}\text { International } \\
\text { Studies }\end{array}$ & & & & & $\mathrm{X}$ & & \\
\hline Computer Labs & & & & & $X$ & & \\
\hline Racial Diversity & & & & & $\mathrm{X}$ & & \\
\hline $\begin{array}{c}\text { Residential } \\
\text { Requirements }\end{array}$ & & & & & $\mathrm{X}$ & & \\
\hline Size of Classes & $\mathrm{X}$ & & & & $\mathrm{X}$ & & \\
\hline $\begin{array}{l}\text { Reputation of } \\
\text { Staff }\end{array}$ & $\mathrm{X}$ & & & & $\mathrm{X}$ & $\mathrm{X}$ & $\mathrm{X}$ \\
\hline $\begin{array}{l}\text { Ranking and } \\
\text { Reviews }\end{array}$ & $\mathrm{X}$ & & & & $\mathrm{X}$ & $\mathrm{X}$ & $\mathrm{X}$ \\
\hline Financial Aid & $X$ & $\mathrm{X}$ & $X$ & & $\mathrm{X}$ & & \\
\hline Cost \& Tuition & $\mathrm{X}$ & $\mathrm{X}$ & $\mathrm{X}$ & & $\mathrm{X}$ & $\mathrm{X}$ & \\
\hline $\begin{array}{l}\text { Length of } \\
\text { Program }\end{array}$ & & & & & $X$ & & \\
\hline Facilities & & & & & & & $X$ \\
\hline $\begin{array}{l}\text { Employment } \\
\text { Prospects }\end{array}$ & & & $\mathrm{X}$ & & & & $\mathrm{X}$ \\
\hline Syllabus & & & & & & & $X$ \\
\hline Offer Ethics & & & & $\mathrm{X}$ & & & \\
\hline $\begin{array}{c}\text { Offer } \\
\text { Sustainability }\end{array}$ & & & & $\mathrm{X}$ & & & \\
\hline Residency Status & & $\mathrm{X}$ & $\mathrm{X}$ & & & & \\
\hline $\begin{array}{c}\text { Academic } \\
\text { Environment }\end{array}$ & $\mathrm{X}$ & $\mathrm{X}$ & $\mathrm{X}$ & & & $\mathrm{X}$ & \\
\hline $\begin{array}{c}\text { Social } \\
\text { Environment }\end{array}$ & & X & $X$ & & & $X$ & \\
\hline $\begin{array}{c}\text { Mentor } \\
\text { Influence }\end{array}$ & & $\mathrm{X}$ & & & & $\mathrm{X}$ & \\
\hline Location & $X$ & $X$ & & & & $X$ & \\
\hline
\end{tabular}

Table 1: Summary Criteria from Prior Studies

The question of a business degree's value has motivated HEIs to improve their business offerings so these can match more closely with current business needs (Sroufe \& Ramos, 2011). To stay competitive, HEIs need to ensure the relevance of their strategies while changing their curricula, globalizing their programs, and 
increasing their integration of environmental and social content to meet the needs of employers and applicants. "Putting globally responsible leadership in corporate responsibility at the heart of business school curricula will also present business schools with a rich opportunity to expand" (Cornuel, 2007: 91).

\section{METHODOLOGY AND IMPORTANT CRITERIA}

We have had limited success in finding research that quantifies the contemporary dynamics and selection criteria business students use in deciding which school best fits them and where they ultimately enroll. Schools could use the quantification of such criteria and of the order of priorities within them to devise strategic maps that align resource allocation more effectively with market demand.

This present study used a convenience sample based on the author's relationships with other educators at participating institutions, one that involved a cross-section of nine business schools across four states and two countries. The geographic dispersion of the participating institutions stretched from the west to the mid-west and eastern part of the U.S. and included two business schools from the U.K. These institutions, some of which were AACSB-accredited, were a mix of public and private entities and had varying enrollment sizes.

The relevance of various selection criteria was first assessed using a mixedmethods approach. The results were then used, in combination with the literature review and frequency of criteria listed in Table 1, to create a pairwise comparison that was calculated using Priority Bridge, a software program that modifies and builds upon the analytic hierarchy process (AHP) technique (T. L. Saaty, personal communication, June 12, 2014). It showed the order of importance of each criterion and the relationship between them.

The mixed-method design was broken down into two separate, workable projects to help ensure cohesiveness. The qualitative analysis focused on the perception of graduate business students to understand what criteria they were using when they selected the business school they had decided to attend as well as to determine each selection criterion's magnitude of influence. This method emphasized the experiences of the participants and their observations of events combined with their judgment. 


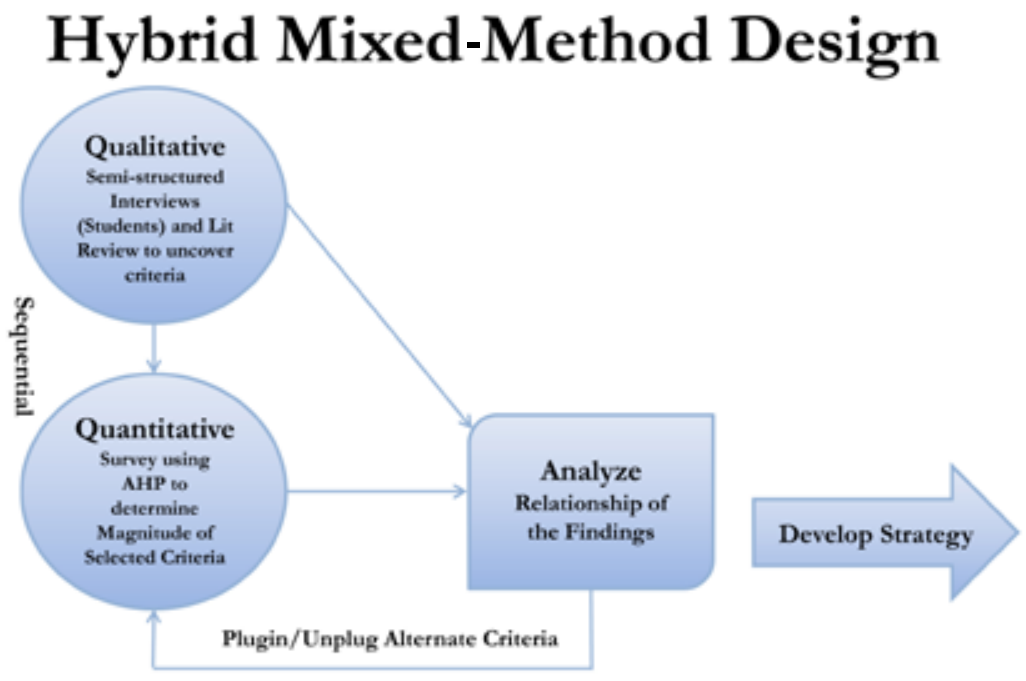

Figure 3: Hybrid Mixed-Methods Design

Figure 3 illustrates the hybrid, sequential mixed-methods design that was used in this study (Creswell \& Plano Clark, 2018). Semi-structured qualitative interviews using open-ended questions were conducted to verify the relevant criteria business students used in selecting the HEI that they were currently attending. The criteria derived from this part of the research were then combined with those derived from prior studies as gathered from the literature review.

Respondents were currently enrolled business school students in the United States and the United Kingdom-the only characteristic that was necessary for them to possess the knowledge required for participation in the study. Other characteristics that were not considered for this study's purposes, such as the respondents' age, previous work experience, and other demographic information, can be the subject of future research. The interview protocol (see Appendix A) was pretested with four faculty colleagues - two involved in recruiting students and two graduate assistantsto help improve the instrument's face validity. Criteria collected from participant responses were coded within and across responses while checking for frequency and newness following a grounded theory approach (Creswell, 2009). The interviews were concluded once saturation was reached, i.e., when new criteria were no longer being gathered. This resulted in 27 criteria. 
The criteria most often mentioned in the qualitative interviews were then combined with criteria derived from past studies (see Table 1) to create a grouping of current and relevant selection criteria. Table 2 shows this "master list" of 29 criteria as mentioned by respondents in the present qualitative analysis and in previous studies and which now includes sustainability in the curriculum (either through classes or as an entire curriculum integrating environmental and social sustainability), on campus (through green school attributes, solar and other renewables, recycling programs, and green buildings), and in general (integrating environmental, social, and financial practices to meet the needs of a current generation without compromising the ability of future generations to meet theirs). Based on these sustainability-related criteria, we found an overlap between curriculum and general sustainability while the sustainable campus was distinctive on its own. Students refer to "sustainability" as a criterion in choosing a program when it is integrated into course content or the curriculum, thereby challenging conventional thinking as to how we will use environmental, social, and financial business practices to meet the needs of current generations without compromising those in the future.

\begin{tabular}{|c|c|}
\hline AACSB Accreditation & Alumni Networking \\
\hline Average Class Size & Average Graduate Starting Salary \\
\hline Distance from Home & Facilities on Campus \\
\hline Faculty Research & Faculty Studies \\
\hline Future Education Opportunities & Housing Costs \\
\hline Intern Programs & Job Placement Assistance \\
\hline Job Potential & Legacy \\
\hline Location & Program Length \\
\hline Program Availability & Reputation \\
\hline Recruiters on Campus & School Size \\
\hline Research Capabilities & Sustainability \\
\hline School Ranking & Sustainable Campus \\
\hline Sustainability in Curricula & Tuition \\
\hline Total Costs & \\
\hline Tuition Assistance & Mention \\
\hline
\end{tabular}

Table 2: Interview Results on Criteria for Selecting a Business School

The top ten criteria from this list-those mentioned most often in the qualitative interviews (based on frequency of criteria within and across responses) and in the 
literature review-were then selected for inclusion in the quantitative comparative analysis study (see Table 3 ).

\begin{tabular}{|c|}
\hline Alumni Networking \\
\hline Job Potential (Career Opportunities) \\
\hline Total Costs (Cost) \\
\hline Future Education Opportunities (Education Potential) \\
\hline Legacy \\
\hline Mentor's Recommendation \\
\hline Program Length \\
\hline Location \\
\hline School Ranking (Rank) \\
\hline Sustainability \\
\hline
\end{tabular}

Table 3: Top Ten Criteria Selected for Quantitative Comparative Analysis

The comparative judgment instrument used in this study questioned the importance of each criterion compared to all other criteria. This was done through AHP, which shed light on the interrelationships between various criteria by allotting a numerical position for each criterion, thereby reducing the complexity of multiplecriteria decisions (Montibeller \& Franco, 2010). The questionnaire involved thus had 45 comparative questions that covered every combination of comparison among the ten criteria.

755 currently enrolled business school students completed the comparative judgment survey, which was conducted from September 2018 to February 2019. The comparative analysis method used allowed for ranking students' decisionmaking processes according to their order of importance. The Priority Bridge software program, which uses a modified version of AHP, was used to automate the analysis and quantify the results.

AHP is a proven multi-criteria decision-making method that can be applied to many types of decisions, from simplified individual choices to labyrinthine, resource-intensive concerns (Saaty \& Vargas, 1985; Stein \& Ahmad, 2009). It is also an excellent tool for measuring the various degrees of importance in the criteria used by consumers when selecting any product or service. In this present study, the criteria used by students in their choices for a business school were measured and evaluated (see a partial sample in Table 4). Indeed, one of the unique applications 
in this use of the modified AHP is its diagnostic capacity to uncover an audience's authentic needs, which can then be used to develop more targeted programs and offerings that fit such needs.

\begin{tabular}{|c|c|c|c|c|c|c|c|c|c|c|c|}
\hline & \begin{tabular}{|c|} 
Alumni \\
Network \\
\end{tabular} & $\begin{array}{c}\text { Career } \\
\text { Opportunities }\end{array}$ & Cost & \begin{tabular}{|c|} 
Education \\
Potential \\
\end{tabular} & Legacy & Length & Mentors & Location & Rank & Sustainability & $\begin{array}{c}\text { Consistency } \\
\text { Ratio }\end{array}$ \\
\hline 1 & 8.74 & 29.63 & 12.05 & 7.94 & 1.52 & 8.68 & 5.7 & 2.91 & 16.23 & 6.6 & 0.2146 \\
\hline 2 & 4.42 & 19.25 & 9.27 & 4.2 & 1.88 & 11.56 & 13.79 & 12.1 & 12.82 & 10.6 & 0.1872 \\
\hline 3 & 4.04 & 31.01 & 17.45 & 13.42 & 2.59 & 9.27 & 5.02 & 3.39 & 4.88 & 8.43 & 0.2609 \\
\hline 4 & 22.38 & 1.27 & 1.73 & 6.95 & 20.48 & 13.32 & 8.16 & 10.76 & 2.34 & 12.6 & 0.316 \\
\hline 5 & 14.22 & 1.04 & 8.86 & 15.99 & 5.65 & 11.29 & 23.41 & 3.63 & 1.53 & 14.4 & 0.3298 \\
\hline 6 & 10.06 & 22.77 & 3.81 & 2.48 & 2.48 & 10.09 & 13.8 & 20.69 & 10 & 3.81 & 0.1585 \\
\hline 7 & 7.09 & 27.31 & 11.88 & 7.25 & 8.22 & 4.9 & 5.28 & 1.69 & 22.19 & 4.19 & 0.3895 \\
\hline 8 & 5.53 & 10.16 & 12.05 & 15.6 & 2.48 & 2.88 & 2.31 & 32.3 & 13.83 & 2.86 & 0.1102 \\
\hline 9 & 8.35 & 17.93 & 8.11 & 13.2 & 4.56 & 5.51 & 17.16 & 16.24 & 6.01 & 2.94 & 0.2774 \\
\hline 10 & 5.46 & 17.58 & 14.1 & 1.89 & 3.15 & 11.37 & 2.39 & 30.67 & 5.13 & 8.27 & 0.1658 \\
\hline 11 & 2.83 & 8.27 & 10.77 & 2.57 & 4.21 & 13.12 & 27.29 & 27.29 & 2.03 & 1.61 & 0.2717 \\
\hline 12 & 12.58 & 20.38 & 23.32 & 2.99 & 1.55 & 9.76 & 5.8 & 4.78 & 16.45 & 2.39 & 0.1608 \\
\hline 13 & 7.85 & 30.28 & 15.17 & 3.5 & 3.35 & 8.1 & 3.06 & 7.89 & 17.11 & 3.69 & 0.1489 \\
\hline 14 & 8.86 & 28.5 & 1.68 & 3.47 & 3.55 & 12.42 & 1.89 & 18.64 & 2.99 & 18.01 & 0.1604 \\
\hline 15 & 1.14 & 17.89 & 1.96 & 3.29 & 1.22 & 7.29 & 1.39 & 5.99 & 17.9 & 41.92 & 0.2589 \\
\hline 16 & 2.61 & 8.32 & 4.05 & 28.68 & 6.07 & 14.86 & 2.36 & 10.97 & 8.73 & 13.35 & 0.1881 \\
\hline 17 & 2.63 & 12.68 & 1.05 & 0.99 & 1.32 & 7.7 & 14.68 & 20.5 & 14.75 & 23.7 & 0.3524 \\
\hline 18 & 3.88 & 16.71 & 2.51 & 2.11 & 10.52 & 18.96 & 2.68 & 24.05 & 3.73 & 14.85 & 0.0662 \\
\hline 19 & 2.5 & 33.57 & 1.06 & 20.46 & 3.39 & 13.75 & 1.59 & 7.45 & 7.17 & 9.06 & 0.2361 \\
\hline 20 & 9.83 & 24.67 & 3.27 & 4.62 & 3.59 & 35.13 & 9.28 & 3.05 & 2.93 & 3.62 & 0.1073 \\
\hline 21 & 10.08 & 19.45 & 4.29 & 3.13 & 3.45 & 23.19 & 2.82 & 8.32 & 4.18 & 20.28 & 0.1272 \\
\hline 22 & 9.31 & 30.87 & 10.42 & 8.67 & 6.44 & 7.87 & 5.2 & 4.43 & 5.08 & 11.71 & 0.2068 \\
\hline 23 & 7.02 & 21.55 & 2.99 & 3.29 & 3.88 & 15.73 & 3.55 & 2.83 & 8.96 & 30.2 & 0.0898 \\
\hline 24 & 1.85 & 18.84 & 20.54 & 2.67 & 1.55 & 27.22 & 5.04 & 7.17 & 9.23 & 5.29 & 0.1804 \\
\hline 25 & 4.78 & 14.56 & 5.79 & 1.66 & 2.26 & 15.49 & 2.09 & 16.43 & 13.16 & 23.77 & 0.1786 \\
\hline
\end{tabular}




\begin{tabular}{|c|c|c|c|c|c|c|c|c|c|c|c|}
\hline & \begin{tabular}{|c|} 
Alumni \\
Network \\
\end{tabular} & $\begin{array}{c}\text { Career } \\
\text { Opportunities }\end{array}$ & Cost & \begin{tabular}{|c|} 
Education \\
Potential \\
\end{tabular} & Legacy & Length & Mentors & Location & Rank & Sustainability & $\begin{array}{c}\text { Consistency } \\
\text { Ratio }\end{array}$ \\
\hline 26 & 12.09 & 13.25 & 16.36 & 1.6 & 2 & 7.73 & 3.65 & 5.02 & 2.91 & 34.59 & 0.3045 \\
\hline 27 & 2.39 & 24.84 & 13.7 & 3.15 & 3.46 & 17.08 & 3.51 & 17.37 & 8.46 & 4.05 & 0.0523 \\
\hline 28 & 3.05 & 19.77 & 2.17 & 2.26 & 17.34 & 31.91 & 2.36 & 8.64 & 9.96 & 2.52 & 0.0748 \\
\hline 29 & 2.7 & 21.85 & 2.23 & 23.81 & 2.12 & 15.57 & 1.9 & 14.66 & 3.79 & 11.37 & 0.0985 \\
\hline 30 & 1.77 & 22.75 & 27.5 & 1.9 & 3.07 & 18.53 & 3.58 & 11.23 & 5.57 & 4.07 & 0.1838 \\
\hline 31 & 2.89 & 25.06 & 13.09 & 2.49 & 3.11 & 21.31 & 2.01 & 11.81 & 3.22 & 15.02 & 0.1166 \\
\hline 32 & 2.63 & 19.47 & 23.61 & 1.45 & 1.59 & 16.24 & 1.45 & 21.04 & 8.93 & 3.6 & 0.0127 \\
\hline 33 & 4.61 & 16.23 & 15.32 & 1.54 & 3.976 & 6.52 & 6.21 & 7.31 & 2.36 & 35.91 & 0.2048 \\
\hline 34 & 3.97 & 15.15 & 3.55 & 2.08 & 9.59 & 42.29 & 7.47 & 7.91 & 4.83 & 3.08 & 0.2411 \\
\hline 35 & 5.71 & 18.94 & 19.2 & 2.38 & 6.19 & 17.56 & 3.07 & 19.12 & 4.38 & 3.43 & 0.0368 \\
\hline 36 & 3.24 & 9.67 & 3.06 & 5.44 & 1.28 & 40.18 & 7.67 & 16.34 & 2.79 & 10.33 & 0.3281 \\
\hline 37 & 3.48 & 14.73 & 2.89 & 3.68 & 7.19 & 10.4 & 36.18 & 6.38 & 8.69 & 6.38 & 0.2232 \\
\hline 38 & 3.51 & 17 & 15.29 & 5.36 & 2 & 16.43 & 1.91 & 3.35 & 6.77 & 28.38 & 0.0589 \\
\hline 39 & 3.95 & 18.27 & 13.15 & 1.67 & 4.82 & 6.57 & 1.36 & 1.92 & 10.72 & 37.56 & 0.1775 \\
\hline 40 & 2.74 & 14.93 & 1.95 & 1.96 & 5.9 & 32.71 & 4.92 & 15.19 & 13.11 & 6.59 & 0.1028 \\
\hline 41 & 5.11 & 31.2 & 2.36 & 3.21 & 4.7 & 20.89 & 10.63 & 8.56 & 4.53 & 8.8 & 0.1583 \\
\hline 42 & 7.52 & 20.47 & 2.23 & 3.72 & 2.27 & 29.49 & 2.39 & 10.33 & 10.09 & 11.49 & 0.121 \\
\hline 43 & 3.89 & 35.11 & 12.65 & 3.14 & 8.66 & 8.05 & 4.45 & 7.18 & 10.98 & 5.89 & 0.1563 \\
\hline 44 & 3.6 & 21.8 & 10.26 & 2.03 & 2.14 & 21.08 & 2.33 & 23.77 & 7.42 & 5.58 & 0.0624 \\
\hline High & 22.38 & 35.11 & 23.61 & 28.68 & 20.48 & 40.18 & 36.18 & 30.67 & 22.19 & 41.92 & $\mathrm{CR}=.0072$ \\
\hline Low & 1.14 & 1.04 & 1.06 & 0.99 & 1.22 & 4.9 & 1.36 & 1.69 & 1.53 & 1.61 & \\
\hline Weight & 5.73 & 5.73 & 8.11 & 5.04 & 4.52 & 17.25 & 5.81 & 11.82 & 8.73 & 11.01 & \\
\hline Std Dev & 4.1566 & 7.8364 & 7.1186 & 8.3416 & 3.9311 & 9.5444 & 7.3525 & 8.0248 & 5.0616 & 10.752 & \\
\hline Mean & 5.873 & 19.6586 & 9.2898 & 5.7702 & 4.5629 & 15.9225 & 6.6543 & 11.8477 & 8.1561 & 12.1998 & \\
\hline
\end{tabular}

Table 4: Partial Sample Matrix of Respondents' Values 


\section{OUTCOMES AND OPPORTUNITIES}

The total matrix of pairwise comparisons, which was derived from 755 completed surveys, had a consistency ratio of 0.0072 , well below the generally accepted 0.01 threshold. We thus concluded that the data was reliable, useful, and of good quality.

\begin{tabular}{|c|c|c|c|}
\hline Future Career Opportunity & 29.47 & Schools Ranking & 6.86 \\
\hline Cost & 16.03 & Alumni Networking & 5.72 \\
\hline Future Education & 12.17 & Length of Program & 5.41 \\
\hline Location & 8.37 & Sustainability & 4.49 \\
\hline Mentor Recommendation & 7.19 & Legacy & 4.29 \\
\hline
\end{tabular}

Table 5: Top Ten Selection Criteria Based on Order of Priorities

Table 5 ranks the top ten selection criteria according to their magnitude of importance. All ten add up to $100 \%$ of the decision on which business school to attend, with the top three resulting in a combined priority of $57.67 \%$. The top five responses equate to a priority of $73.23 \%$. Such information is important for resource allocation decisions especially for institutions that have limited capital. Indeed, the various priorities of importance in the decision-making process of students reveal some significant differences. According to this sample from nine different schools, for instance, the ability of an institution to provide graduates with future career opportunities is almost twice as important as the cost of attending the school.

Two of the criteria listed here would not have been on any similar list 20 years ago. Only a few graduate business schools at the turn of the century were offering degrees combined with a short program, an important criterion in this present study albeit one overshadowed significantly by future career opportunities. Sustainability, while more common today compared to when a similar study was done at Carnegie Mellon University in 1978, is still not widely thought of either in business or in education.

The relevance of this study for HEIs is in the use of the AHP method, measures of authenticity and legitimation that it allows, and strategies for resource allocation, overcoming inertia and time constraints, and competitive advantage marketing that it supports. The significance of this use of AHP as a diagnostic tool was demonstrated well in this project, adding to its reliability in MCDA. The same type of approach can be used for projects in other schools that are trying to gain a better scope 
of consumers' perceptions. Indeed, the niche of a HEI should be attuned closely with the needs of its audience and with all its stakeholders. If prospective students expect that an institution will best prepare them for future job opportunities, that institution's niche needs to reflect as much. Having better insights into the perceptions of consumers will also allow for the improved allocation of resources. Given that the human and economic capital of most organizations, including many institutions of higher education, is limited, such must be expended in the most advantageous ways possible. To this end, we find that sustainability today is not only in the consciousness of applicants but also an opportunity for further development, differentiation, and niche alignment.

Given that program length and sustainability, which are among the priorities that today's prospective students look at, would not have been on any type of list ten years ago also shows that time changes perceptions about what is essential. Thus, while change may be difficult, a failure to overcome inertia will nevertheless increase mortality rates for those institutions that do not follow the evolving needs of students. All the criteria listed here, including but not limited to sustainability, need to have an impact on the marketing strategies of higher education institutions. The better they understand their audience's needs, the more closely attuned their strategy will be, and hence the more likely the institution will survive hard times and be successful.

The insights derived from the results of this study may be summarized as follows:

- $\quad$ Prospective students place the greatest priority in a school's ability to help them get the jobs they want.

- $\quad$ Prospective students want to complete the program as quickly as possible but not at the expense of job opportunities.

- The location of the HEI is of great importance.

- It is now possible that sustainability is an essential program element. It could rise in the order of priorities if it is used for program differentiation or niche alignment. 
- Business schools need to conduct this type of research on their actual and/or prospective student populations. Doing so will help them determine the best match and allocation of resources and augment current administrative tools. It can also help identify opportunities for curriculum changes as well as improve alignment with applicants and a global marketplace that value sustainable business practices.

\section{DISCUSSION}

While it does cover broad aspects, the purpose of this study is to highlight its findings on sustainability and get management for global sustainability on the radar of university administrators and scholars, particularly as a way to see the interconnected issues that encompass, but are not limited to, the alignment of business programs with the needs of students and the marketplace. We do this by exploring how to determine the criteria students use in their selection process and then quantifying those selection criteria. The value of this study is also evident in its use of a mixed-methods research approach, where students' selection criteria, along with the order of priorities among such, can be both qualified and quantified.

Through a greater understanding of candidates' priorities in choosing between graduate business schools, institutions will be able to design programs that more closely match the needs and wants of potential students. We see this as leading to more positive enrollment and retention metrics. More efficient resource allocation can also help schools to produce offerings that include sustainability as well as improve the results of both potential candidates and students who will finally be exposed to elements of sustainability that include, but are not limited to, the U.N. SDGs.

There is something innately paradoxical about the top four criteria showing a desire from students to be educated in those skills that modern international businesses are currently seeking while business schools, for the most part, continue to produce graduates in the same manner that they have been doing so for the last half-a-century. It has been observed that only a few institutions incorporate these skills, which include sustainability and responsible leadership, into their curricula (Laszlo, Sroufe, \& Waddock, 2017). Indeed, a study conducted in 2009 found that 
most AACSB-accredited universities did not even include relevant coursework in their programs (Rubin \& Dierdorff, 2011). The marketplace is changing, and so are applicants to business schools. Both this study and others show interest in the importance of responsible business management and of students calling for businesses and business schools to integrate sustainability so they can attract and retain talent (U.N. PRME; see Net Impact, 2012; Franceschini et al., 2015).

Graduates who can visualize the bonds between career opportunities, costs, rankings, networks, and environmental and social factors will produce more resilient businesses that are ready for an uncertain future. The results of this study show that students are looking for educational environments that will help them develop the mental attributes required for addressing issues of sustainable business practice as previously outlined by Sroufe, Sivasubramaniam, Ramos, and Saiia (2014). Business school programs can use these results to enhance and sustain student loyalty as well as generate differentiators that are essential for creating a good brand (Gopalan et al., 2008).

The results of this study also point to an increased desire for knowledge about return on investment and career opportunities. Students need skills for creating relationships with multiple networks so they can suggest changes in the marketplace that have the potential to become a reality (Elmes, Jiusto, Whiteman, Hersh, \& Guthey, 2012).

Business programs need to change, yet changing curricula is very difficult (Hannan et al., 2006). Research results similar to those in this study can be used to help minimize resistance to change as well as enhance communication about the growing importance of sustainability. Given that students are calling for more sustainability and not less of it from businesses and universities, it is time for HEIs to catch up with these trends-or get out in front of them-through innovative programs that equip students with the skills to meet the grand challenges of our era.

Business schools are strongly advised, then, given that this mixed-methods study shows promise for an improved understanding of stakeholders and of the HEI marketplace, to consider utilizing similar methods. HEIs need to continue improving their market orientation in a more resilient manner so they can improve how they respond to and communicate with stakeholders both inside and outside the institution. 


\section{LIMITATIONS AND OPPORTUNITIES FOR FUTURE RESEARCH}

The limitations of the qualitative portion of the research stem from open-ended questions and a limited sample. While results were cross-checked to minimize any bias that may have affected the coding of the transcripts, it is difficult to eliminate bias completely in a qualitative study. The small number of schools in the sample was also a limitation, as was their geographical coverage, which focused mainly on institutions in the U.S. and U.K. We assume that criteria for students in different parts of these countries or in other countries entirely will vary.

The study also did not differentiate between the individual characteristics of each institution such as its size, whether it was public or private, whether it had any religious affiliations, or its ranking and reputation. We also did not differentiate between respondents based on age, sex, previous work experience, nationality, or any type of demographic information. Such information was nevertheless collected, however, should any future studies wish to find additional meaning in the differences between subgroup responses.

Future research using this methodology can either replicate previous studies to prove or disprove prior assumptions or glean insights into new and emerging criteria such as the sustainability elements found in the 17 U.N. SDGs. Post-pandemic studies can help reveal how the needs of students change over time and which criteria emerge as more critical in the future. Teaching institutions can also replicate the present research, which may prove to be a useful tool for better allocation of finite resources to meet diverse stakeholders' needs. It can be a challenge as well for accreditation organizations such as the AACSB and student groups such as Net Impact to help in conducting data collection so emerging issues that should be part of the business school curriculum can be identified. Business schools that use these methods in their recruitment processes will be able to uncover new and emerging criteria, measure its magnitude of importance, and design their strategy to meet the changing needs of customers. 


\section{CONCLUSIONS}

Business school graduates can either add value to or take it away from society. To succeed in the environments that they face, higher education institutions must improve on their ability to provide what customers want and stop doing business as usual within a neoliberal paradigm of economics (Waddock, 2020). Indeed, we have even hinted at the increased probabilities of extinction for some business schools as a motivator for change.

The criteria uncovered in this study show that business schools have an opportunity to develop and design innovative courses along with their curricula and do not have to restrict themselves to a myopic focus on neoliberal economics. New offerings can align with career opportunities that help eliminate poverty and hunger (SDG 1 and 2). These can provide learning about business models that contribute to good health and well-being (SDG 3) as part of high-quality education (SDG 4) from HEIs that are recommended by mentors and others to potential business school applicants. We can also envision programs that teach about and enable gender equality and a reduction in overall inequalities (SDG 5 and 10). The business of business schools—if we may use a Milton Friedman-esque play on words—can be the moulding of graduates that have the skills necessary for developing affordable and clean energy (SDG 7); promoting decent work and economic growth (SDG 8) as well as industry, innovation, and infrastructure (SDG 9); building sustainable cities and whole communities (SDG 11) that practice responsible consumption and production (SDG 12); and establishing peace, justice, and strong institutions (SDG 16). These goals are at the heart of evolving business school rankings, AACSB accreditation requirements, and what some specialized programs as signatories to the U.N. PRME have already been attempting. New opportunities for the management of global sustainability also include working toward the goals for clean water and sanitation (SDG 6), climate action (SDG 13), and life below water (SDG 14) and on land (SDG 15) as well as on partnerships for the SDGs (SDG 17). There are now opportunities to reinvent "business as usual," enable business school graduates to become part of resilient enterprises that contribute to achieving global sustainability, and create socially just ways for all species to thrive forever. It will be an excellent legacy to work for and achieve.

The collection, understanding, and communication of future business school students' essential criteria are vital to any program. Implementing a dynamic tool 
using robust data and information to help collect and respond to the changing nature of stakeholders' needs will ensure program longevity (Parvu \& Ipate, 2012). Nevertheless, adjusting courses, content, and program offerings will be a fundamental challenge for all schools (Paraschivescu \& Radu, 2011). This study's findings highlight the importance of having relevant content experts who understand and can integrate global sustainability into curriculum, rankings, branding efforts, and career matching after graduation.

We have thus contributed both a methodology and a basis for a better understanding of the criteria prospective students use to choose graduate business schools, the most crucial of which are future career opportunities and newly emerging ones, particularly sustainability. This approach can augment our understanding of these criteria and their importance to the decision-making process while enabling informed strategies for enrollment, retention, accreditation, and program relevance. It can provide not only data to help overcome a lack of differentiation and resistance to change but also the ability to address global sustainability issues in the design of courses, programs, and pedagogy. It will be ideal, therefore, for course and program development to meet the changing needs of global sustainability and future business students.

\begin{tabular}{|l|}
\hline Graduate School: \\
\hline Code: \\
\hline Background Information: \\
\hline A1: What is your name? \\
\hline A2: Are you registered as an in-state or an out-of-state student? \\
\hline A3: Are you registered in the full-time, part-time, or executive program? \\
\hline A4: How long was your previous work experience? \\
\hline A5: What was your GMAT score? \\
\hline A6: What was your undergraduate GPA? \\
\hline A7: Where was your undergraduate degree earned? \\
\hline A8: What was your undergraduate major? \\
\hline A9: What is the amount of total annual loans you are taking for school? \\
\hline A10: What is the total amount in fellowships and grants that you are receiving? \\
\hline
\end{tabular}


Interview Questions: The following questions are designed to find out what was important to you in choosing a program.

1: Why are you pursuing an MBA?

2: What other institutions did you apply to?

3: What stood out to you about those other institutions?

4: What influenced your decision to attend (Insert Institution Name here) with the major influence first?

Appendix A: Interview Protocol

\section{REFERENCES}

3BL Media. 2020. 90\% of S\&P 500 Index companies publish sustainability reports in 2019, G\&A announces in its latest annual 2020 flash report. July 16. Available at https://www.3blmedia.com/News/90-SP-500-Index-Companies-PublishSustainability-Reports-2019-GA-Announces-its-Latest-Annual\#: :text=In\%20 the $\% 20$ just $\% 2$ Dcompleted $\% 202020$, were\%20publishing\%20a\%20 sustainability\%20report (accessed October 28, 2020).

Arnold, L. R., Chakravarty, A. K., \& Balakrishnan, N. 1996. Applicant evaluation in an executive MBA program. Journal of Education for Business, 71(5): 277-283.

Aspen Institute. 2008. Aspen Institute releases green MBA guide. June 23. Available at https://www.aspeninstitute.org/news/press-release/aspen-institute-releasesgreen-mba-guide/ (accessed October 28, 2020).

Bailey, J. S. 1991. Marketing behavior analysis requires different talk. Journal of Applied Behavior Analysis, 24(3): 445-448.

Barnett, C. K., \& Shore, B. 2009. Reinventing program design: Challenges in leading sustainable institutional change. Leadership \& Organization Development Journal, 30(1): 16-35.

Barth, M. 2013. Many roads lead to sustainability: A process-oriented analysis of change in higher education. International Journal of Sustainability in Higher Education, 14(2): 160-175. 
Blackburn, G. 2011. Which Master of Business Administration (MBA)? Factors influencing prospective students' choice of MBA programme-An empirical study. Journal of Higher Education Policy and Management, 33(5): 473-483.

Blass, E., \& Hayward, P. 2014. Innovation in higher education: Will there be a role for "the academe/university" in 2025? European Journal of Futures Research, 2: 41.

Bower, J. L., \& Paine, L. S. 2017. The error at the heart of corporate leadership. Harvard Business Review, 95: 50-60.

Brauer, D. 2012. AACSB accreditation as an intervention to boost applications at graduate business schools. Doctoral dissertation, Durham University Business School, England.

Brown, A. 2013. All bar one S\&P 500 firms made sustainability disclosures in 2012. IR Magazine, May 2. Available at https://www.irmagazine.com/esg/all-bar-onesp-500-firms-made-sustainability-disclosures-2012 (accessed October 28, 2020).

Card, M. A., \& Card, K. A. 2007. Public sector competitive strategies: Understanding post secondary distance education in South Dakota. International Journal of Public Administration, 30(5): 461-481.

CarringtonCrisp, EFMD, \& ABS. 2013. Executive summary 2013: A change of direction? London: CarringtonCrisp.

Carter, S., \& Yeo, C.-M. A. 2009. My place or yours? Perceptions of, and selection choice criteria for, higher education institutions: The case of UK and Malaysian students. International Journal of Economics and Business Research, 1(2): 165-190.

Chapman, D. W. 1981. A model of student college choice. The Journal of Higher Education, 52(5): 490-505.

Chapman, R. G. 1986. Toward a theory of college selection: A model of college search and choice behavior. Advances in Consumer Research, 13: 246-250.

Christensen, L. J., Peirce, E., Hartman, L. P., Hoffman, W. M., \& Carrier, J. 2007. Ethics, CSR, and sustainability education in the Financial Times top 50 global 
business schools: Baseline data and future research directions. Journal of Business Ethics, 73(4): 347-368.

Cornuel, E. 2007. Challenges facing business schools in the future. Journal of Management Development, 26(1): 87-92.

Creswell, J. W. 2009. Research design: Qualitative, quantitative, and mixed methods approaches (3rd ed.). Thousand Oaks, CA: Sage Publications.

Creswell, J. W., \& Plano Clark, V. L. 2018. Designing and conducting mixed methods research (3rd ed.). Thousand Oaks, CA: Sage Publications.

Datar, S. M., Garvin, D. A., \& Cullen, P. G. 2010. Rethinking the MBA: Business education at a crossroads. Boston, MA: Harvard Business Press.

Dobson, A., Quilley, S., \& Young, W. 2010. Sustainability as competitive advantage in higher education in the UK. International Journal of Environment and Sustainable Development, 9(4): 330-348.

Elmes, M. B., Jiusto, S., Whiteman, G., Hersh, R., \& Guthey, G. T. 2012. Teaching social entrepreneurship and innovation from the perspective of place and place making. Academy of Management Learning \& Education, 11(4): 533-554.

English, D. J. 2012. Graduate school choice: An examination of individual and institutional effects. Doctoral dissertation, North Carolina State University. ProQuest Dissertations Publishing.

Essary, M. 2011. Exploring the development of a competitive-advantage model for online education in a small state university. Doctoral dissertation, Northcentral University. ProQuest Dissertations Publishing.

Franceschini, L., Wang, J., \& Cort, T. 2015. Rising leaders on environmental sustainability and climate change: A global survey of business students. New Haven, CT: Yale Center for Business and the Environment, Global Network for Advanced Management, and World Business Council for Sustainable Development. Available at https://cbey.yale.edu/sites/default/files/2019-09/ 
Rising\%20Leaders\%20on\%20Environmental\%20Sustainability\%20and\%20 Climate\%20Change\%20Dec_2015.pdf.

Gatfield, T., \& Chen, C.-H. 2006. Measuring student choice criteria using the theory of planned behaviour: The case of Taiwan, Australia, UK, and USA. Journal of Marketing for Higher Education, 16(1): 77-95.

Gerard, L. 2014. Annual Net Impact survey highlights impact MBA program trends and rankings. Net Impact, Sept. 2. Available at www.netimpact.org/about/pressreleases/annual-net-impact-survey-highlights-impact-mba-program-trends-andrankings.

Ghoshal, S. 2005. Bad management theories are destroying good management practices. Academy of Management Learning \& Education, 4(1): 75-91.

Giacalone, R. A., \& Thompson, K. R. 2006. Business ethics and social responsibility education: Shifting the worldview. Academy of Management Learning \& Education, 5(3): 266-277.

Gopalan, S., Pagiavlas, N., \& Jones, T. 2008. Branding MBA programs: Are they sufficiently related to an institution's strategy? Allied Academies International Conference: Proceedings of the Academy of Strategic Management, 7(2): 14-19.

Gupta, S., \& Zeithaml, V. 2006. Customer metrics and their impact on financial performance. Marketing Science, 25(6): 718-739.

Hammond, K. L., Harmon, H. A., \& Webster, R. L. 2007. University performance and strategic marketing: An extended study. Marketing Intelligence \& Planning, 25(5): 436-459.

Hammond, K. L., \& Webster, R. L. 2011. Market focus in AACSB member schools: An empirical examination of market orientation balance and business school performance. Academy of Marketing Studies Journal, 15(1): 11-22.

Hannan, M. T., Baron, J. N., Hsu, G., \& Koçak, Ö. 2006. Organizational identities and the hazard of change. Industrial and Corporate Change, 15(5): 755-784. 
Hemsley-Brown, J., \& Oplatka, I. 2006. Universities in a competitive global marketplace: A systematic review of the literature on higher education marketing. International Journal of Public Sector Management, 19(4): 316-338.

Henle, C. A. 2006. Bad apples or bad barrels? A former CEO discusses the interplay of person and situation with implications for business education. Academy of Management Learning \& Education, 5(3): 346-355.

Hoffman, A. J. 2018. The next phase of business sustainability. Stanford Social Innovation Review, 16(2): 34-39.

Ivy, J. 2008. A new higher education marketing mix: The 7Ps for MBA marketing. International Journal of Educational Management, 22(4): 288-299.

Kallio, R. E. 1995. Factors influencing the college choice decisions of graduate students. Research in Higher Education, 36(1): 109-124.

Kelderman, E., \& Gardner, L. 2019. The looming enrollment crisis: How colleges are responding to shifting demographics and new student needs. Washington, DC: Chronicle of Higher Education.

Laszlo, C., Sroufe, R., \& Waddock, S. 2017. Torn between two paradigms: A struggle for the soul of business schools. AI Practitioner, 19(2): 108-119.

Lozano, R., Ceulemans, K., \& Seatter, C. S. 2015. Teaching organisational change management for sustainability: Designing and delivering a course at the University of Leeds to better prepare future sustainability change agents. Journal of Cleaner Production, 106: 205-215.

Montgomery, D. B., \& Ramus, C. A. 2011. Calibrating MBA job preferences for the 21st century. Academy of Management Learning \& Education, 10(1): 9-26.

Montgomery, M. 2002. A nested logit model of the choice of a graduate business school. Economics of Education Review, 21(5): 471-480.

Montibeller, G., \& Franco, A. 2010. Multi-criteria decision analysis for strategic decision making. In C. Zopounidis \& P. M. Pardalos (Eds.), Handbook of multicriteria analysis: 25-48. Berlin: Springer. 
Mullen, A. L., Goyette, K. A., \& Soares, J. A. 2003. Who goes to graduate school? Social and academic correlates of educational continuation after college. Sociology of Education, 76(2): 143-169.

Navarro, P. 2008. The MBA core curricula of top-ranked US business schools: A study in failure? Academy of Management Learning \& Education, 7(1): 108-123.

Negro, G., Hannan, M. T., Rao, H., \& Leung, M. D. 2007. No barrique, no Berlusconi: Collective identity, contention, and authenticity in the making of Barolo and Barbaresco wines. Stanford University Graduate School of Business Research Paper No. 1972. Stanford, CA: Stanford Graduate School of Business.

Net Impact. 2012. Talent report: What workers want in 2012 | Executive summary. Available at https://www.netimpact.org/sites/default/files/documents/whatworkers-want-2012-summary.pdf (accessed January 2018).

Net Impact. 2014. Business as unusual: The social \& environmental impact guide to graduate programs - for students by students. Available at https://netimpact. org/sites/default/files/documents/business-as-unusual-2014.pdf.

Padlee, S. F., Kamaruddin, A. R., \& Baharun, R. 2010. International students' choice behavior for higher education at Malaysian private universities. International Journal of Marketing Studies, 2(2): 202-211.

Paraschivescu, V., \& Radu, C. E. 2011. Higher education, a resource for sustainability. Economy Transdisciplinarity Cognition, 14(1): 115-120.

Parvu, I., \& Ipate, D. M. 2012. Knowing our "clients" for a better management in higher education services. Economics, Management, and Financial Markets, 7(4): 703-711.

Pfeffer, J., \& Fong, C. T. 2002. The end of business schools? Less success than meets the eye. Academy of Management Learning \& Education, 1(1): 78-95.

Punj, G. N., \& Staelin, R. 1978. The choice process for graduate business schools. Journal of Marketing Research, 15(4): 588-598. 
Rasche, A., Gilbert, D. U., \& Schedel, I. 2013. Cross-disciplinary ethics education in MBA programs: Rhetoric or reality? Academy of Management Learning \& Education, 12(1): 71-85.

Reeves, M., \& Whitaker, K. 2020. A guide to building a more resilient business. Harvard Business Review, July 2. Available at https://hbr.org/2020/07/a-guideto-building-a-more-resilient-business.

Rubin, R. S., \& Dierdorff, E. C. 2009. How relevant is the MBA? Assessing the alignment of required curricula and required managerial competencies. Academy of Management Learning \& Education, 8(2): 208-224.

Rubin, R. S., \& Dierdorff, E. C. 2011. On the road to Abilene: Time to manage agreement about MBA curricular relevance. Academy of Management Learning \& Education, 10(1): 148-161.

Rusinko, C. A. 2010. Integrating sustainability in higher education: A generic matrix. International Journal of Sustainability in Higher Education, 11(3): 250-259.

Saaty, T. L., \& Vargas, L. G. 1985. Modeling behavior in competition: The analytic hierarchy process. Applied Mathematics and Computation, 16(1): 49-92.

Shimizu, N., \& Tamura, A. 2012. Connecting capital budgeting practice with the Miles-Snow strategic type: A novel managerial accounting approach. Global Conference on Business and Finance Proceedings, 7(1): 45-56.

Simpson, R. 2006. Masculinity and management education: Feminizing the MBA. Academy of Management Learning \& Education, 5(2): 182-193.

Slater, D. J., \& Dixon-Fowler, H. R. 2010. The future of the planet in the hands of MBAs: An examination of CEO MBA education and corporate environmental performance. Academy of Management Learning \& Education, 9(3): 429-441.

Sroufe, R. 2018. Integrated management: How sustainability can create value within any business. Bingley, UK: Emerald Publishing Limited. 
Sroufe, R., \& Ramos, D. 2011. MBA program trends and best practices in teaching sustainability: Live project courses. Decision Sciences Journal of Innovative Education, 9(3): 349-369.

Sroufe, R., Sivasubramaniam, N., Ramos, D., \& Saiia, D. 2014. Aligning the PRME: How study abroad nurtures responsible leadership. Journal of Management Education, 39(2): 244-275.

Stein, E. W., \& Ahmad, N. 2009. Using the analytical hierarchy process (AHP) to construct a measure of the magnitude of consequences component of moral intensity. Journal of Business Ethics, 89(3): 391-407.

Tavares, O., \& Cardoso, S. 2013. Enrolment choices in Portuguese higher education: Do students behave as rational consumers? Higher Education, 66(3): 297-309.

Thomas, S. 2011. What drives student loyalty in universities: An empirical model from India. International Business Research, 4(2): 183-192.

Vander Schee, B. A. 2009. Embracing enrollment management: A comprehensive approach to college student marketing. Academy of Marketing Studies Journal, 13(1): 1-24.

Waddock, S. 2020. Will businesses and business schools meet the grand challenges of the era? Sustainability, 12(15): 6083.

WCED [World Commission on Environment and Development]. 1987. Our common future. Oxford and New York: Oxford University Press.

Webster, R. L., Hammond, K. L., \& Rothwell, J. C. 2010. Customer and market orientation within AACSB member business schools: Comparative views from three levels of administrators. American Journal of Business Education, 3(7): 79-92.

Zhang, L. 2005. Advance to graduate education: The effect of college quality and undergraduate majors. The Review of Higher Education, 28(3): 313-338. 
Robert Sroufe is the Murrin Chair of Global Competitiveness and a Professor of Sustainability and Supply Chain Management at Duquesne University's Palumbo Donahue School of Business. He develops research and project-based pedagogy within the globally top-ranked MBA Sustainable Business Practices program. Winner of numerous teaching awards, he has published international and national refereed journal articles and multiple books on sustainable business practices. His research interests include understanding the drivers of sustainability performance, management systems, Integrated Management and Integrated Bottom Line (IBL) performance, integration and change management, high-performance buildings, Building Based Learning (BBL), strategic sustainable development, and management education.

David B. Brauer earned his PhD in Decision Science and Organizational Ecology from Durham University, U.K. He is currently the Director of the Sales Institute at West Virginia University and an Assistant Professor of Marketing at the John Chambers School of Business and Economics, West Virginia University. 